\title{
FOREST RECOLONIZATION MONITORING BASED ON HR AND VHR IMAGERY: THE CASE OF THE MAIDO FOREST FIRE EXPLOITING PLÉIADES AND SPOT KALIDEOS DATABASE
}

\author{
Mathilde Caspard ${ }^{1}$, Hervé Yesou ${ }^{1}$, Arnaud Selle $^{2}$, Claire Tinel ${ }^{2}$, Pierre Tessier $^{3}$, Arnaud Durand $^{1}$, \\ Stephen Clandillon ${ }^{1}$, Paul de Fraipont ${ }^{1}$ \\ 1: SERTIT, Strasbourg, mathilde.caspard@sertit.u-strasbg.fr \\ 2: CNES, Toulouse \\ 3: SEAS-OI, Saint-Pierre, La Réunion
}

\begin{abstract}
Résumé
Cet article explore les potentialités des images Pléiades pour le suivi de la recolonisation du Massif du Maido dans un contexte post-incendie. Ce site, situé au cœur du Parc National de la Réunion et classé patrimoine mondial de I'UNESCO a été touché par des incendies fin octobre 2011, affectant une surface estimée à 2700 ha peuplée en majeur partie par des espèces endémiques.

Pour comprendre l'état et le comportement phénologique de la végétation pré et post-incendie, cette étude exploite la base de données SPOT KALIDEOS (depuis 2005) couplée à des informations de terrain. Puis, une série d'images Pléiades post-incendie, acquise de juin 2012 à septembre 2013 complétée d'une image Worldview-2 pré-évènement ont été utilisées pour évaluer l'apport de la très haute résolution spatiale dans le cadre du suivi de la recolonisation du massif à l'échelle de la placette.

Au total 66 images SPOT et de 10 images à très haute résolution de type Pléiades ont été intégrées et exploitées. L'analyse d'indices de végétation type NDVI ou TSAVI sur la série temporelle a permis de mettre en évidence du cycle de la végétation du massif aussi bien en dehors de phases de perturbation qu'au plus près de l'évènement et après. L'indice NRI a permis de la caractérisation de la recolonisation de la végétation post-incendie.

La texture apportée par les images à très haute résolution a permis de confirmer une reprise végétale et de qualifier ce phénomène de recolonisation constitué d'une végétation apparemment différente de celle d'origine.
\end{abstract}

Mots-clés : Réunion, Maido, Pléiades, SPOT, recolonisation, incendies, KALIDEOS

\section{Abstract}

This paper explores the potential of the Pléiades images for the monitoring of the recolonization of Maido Forest in a post-fire framework. This site, located in the heart of the National Park of Reunion and classified as a UNESCO World Heritage Site, has been affected by several wildfires late October 2011 , ravaging an area of approximately 2700 ha covered mostly by endemic species.

To understand the state and the phenological behavior of pre and post fire vegetation, this study uses the SPOT KALIDEOS archive (since 2005) combined with field information. Then, a series of post-fire Pleiades image acquired from June 2012 to September 2013 plus one pre-event Worldview-2 image were used to assess the contribution of very high spatial resolution to monitor forest recolonization at a plot scale.

A total of 66 SPOT and 10 very high resolution (Pléiades and WorldView-2) images have been integrated and exploited. Spectral vegetation indexes like NDVI or TSAVI have been analyzed on multi-temporal series and have highlighted the forest vegetation cycle as well as outside perturbation phases than closer to the event and after. The NRI index allowed characterization and monitoring of post-fire vegetation recolonization.

Finally, the texture provided by the very high resolution images helped to confirm vegetation recovery and to qualify this recolonization phenomenon consisting of a vegetation apparently different from the original.

Keywords: Reunion Island, Maido, Pléiades, SPOT, recolonization, forest fires, KALIDEOS

\section{Introduction}

\subsection{Context of the study}

In the afternoon of the 25th of October 2011, several wildfires were reported to be burning in the Maido forest, located in the heart of the Reunion Island National Park, which is classified as a UNESCO world heritage site. According to the report published afterwards by the prefecture, about 2700 hectares were affected (Figure 1). For one week, the SERTIT Rapid Mapping Service has produced a satellite imagery map of the situation, with a daily up-date delivery (Figure 2) (http://sertit.u-strasbg.fr/RMS/action.php?id=5574032311).

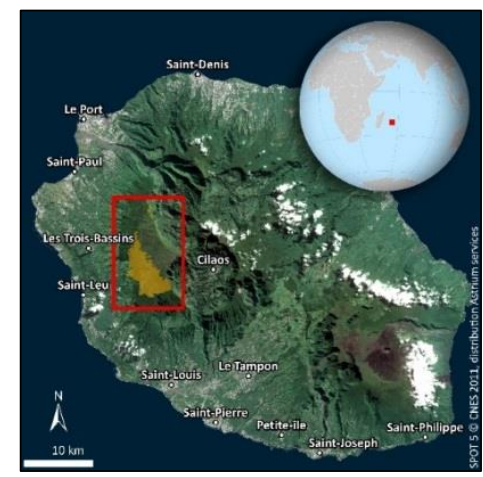

Figure 1 : Location of study area (CSERTIT 2011). 
After this crisis period, SERTIT was mandated by CNES to study forest regeneration with a multi-temporal (2005 to 2013) satellite imagery series. This series is composed of SPOT4 and SPOT5 data from the KALIDEOS database plus Pléiades images obtained during the Pléiades Users Thematic Commissioning and one Worldview-2 image acquired as a reference before the fire event.

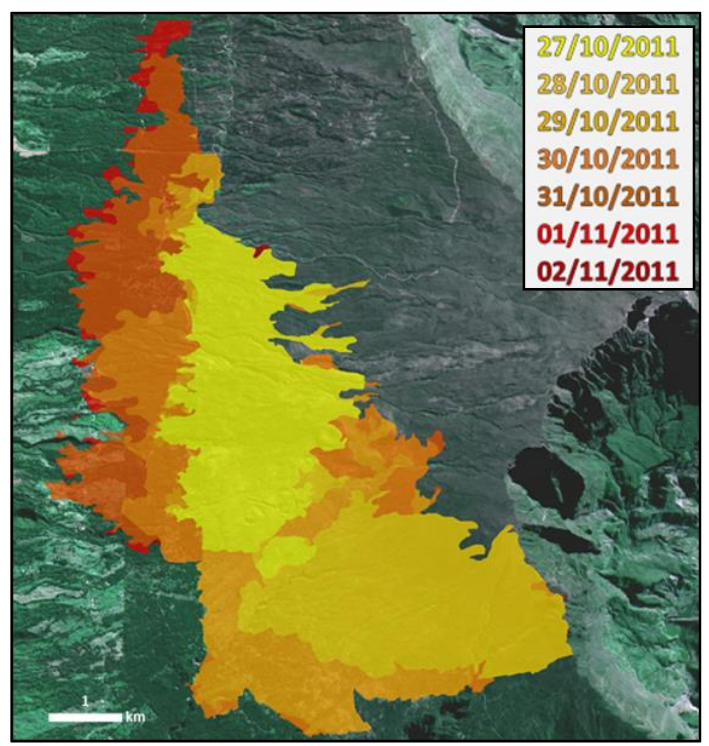

Figure 2 : 2011 Maido forest fire monitoring.

Forest fires can create profound changes in the structure and function of an ecosystem. Unlike some geographical areas (Mediterranean countries or California for example) where this type of event can play an important role in maintaining ecosystems (Hanes, 1988), fires of human origin triggered in Maido represent significant biodiversity losses impacting endemic species. In this context, monitoring vegetation regeneration is important for resource management and to organize a program to revegetate, reducing soil erosion.

During the last few decades, the satellite imagery has proven its potential in vegetation recovery monitoring, but most studies have covered particularly fire sensitive sectors like the northern Mediterranean basin (G .H. Mitri et al. 2003, Achim Röder et al 2007, George P. Petropoulos et al 2014) or the Californian area (D. Riano et al 2001). Few references are found on fires affecting tropical areas like the Reunion Island. Furthermore, these studies are often based on high resolution image analysis like Landsat, Hyperion or SPOT, but not on very high spatial resolution images such as Pléiades.

The most common image analysis approaches focusing on vegetation recovery use classifications (Jakubauskas, Lulla, and Mausel, 1990) and/or spectral vegetation indexes vegetation (Diaz-Delgado et al., 2003; Hope, Tague, and Clark, 2007). In the wide range of available techniques, those based on spectral vegetation indexes are the most prominent particularly with the use of NDVI (Rouse, Haas, Schell, and Deering, 1973) as in the present study. Another interesting index, the TSAVI Transformed Soil-Adjusted
Vegetation Index (Baret F and Guyot G., 1991) which aims to minimize soil brightness reflectance, will be applied in this study as a comparison to the NDVI bearing in mind the large bare soil/rock landcover in the area. The NRI index (Chabaane Z. et al, 2005), based on NDVI differences seems to be adapted to highlight vegetation regeneration.

\subsection{Objectives and organisation of this paper}

The objective of this paper is to highlight vegetation regeneration over the 2011 burn scar. To enable this itis important to have an idea of the "normal" state of the area and its behavior over the seasons before this event and this is possible thanks to a rich pre-crisis imagery database. Moreover, having field data facilitates the analysis of the spatial, spectral and temporal characteristics of the data.

This paper is organised as follows: Section 2 presents the study area, the database and its preparation, section 3 explains the method used to evaluate the vegetation cover; section 4 concerns vegetation regeneration, and section 5 concludes this paper.

\section{Study area and geo-spatial database}

\subsection{Location}

The study area extends over the "Hauts-sous-le-Vent" forest massif on the "Maido" and "Grand Bénare" slopes, on the western side of Reunion Island above the town of Saint-Paul. Culminating at 2600 meters, Maido is an exceptional UNESCO world heritage site given its situation above the Mafate cirque.

Reunion Island vegetation is distributed according to height and rainfall levels (Cadet, 1980) also being linked to trade wind direction. The Maido forest is located in the north-western part of the island between $1200 \mathrm{~m}$ and $2600 \mathrm{~m}$ altitude. The "Hauts-sous-le-Vent" forest massif is recognized for its richness and the uniqueness of its natural heritage. Itis a unique ecosystem of endemic flora adapted to the harsh high mountain environmental conditions (Cadet, 1974).

Four main types of vegetation are present in the Maido area (Figure 3):

Ericacea (heath vegetation): Low-lying vegetation (maximum 4-5m height) located above the $2000 \mathrm{~m}$ contour. Ericacea are characterised by endemic shrub species: Erica reunionensis (green heath) and Stoebe passerinoides (white heath). This type represents $60 \%$ of the vegetation cover of the study area.

Acacia heterophylla (highland tamarins): This is an endemic forest tree species, present in the upper part of the meso-thermal level between $1500 \mathrm{~m}$ and $1900 \mathrm{~m}$ altitude. The many fires in this sector have contributed to its mono-dominance.

Acacia mearnsii (black wattle): This is an exotic tree species planted for its tannins. This constitutes transitional vegetation between mesothermal and altimontain levels.

Cryptomeria japonica (Japanese cedar): Cryptomeria are exotic tree species introduced to the island in 1953. They are planted between 900 and 1400 $\mathrm{m}$ altitude and are mainly used for logging and burnt soil restoration. 


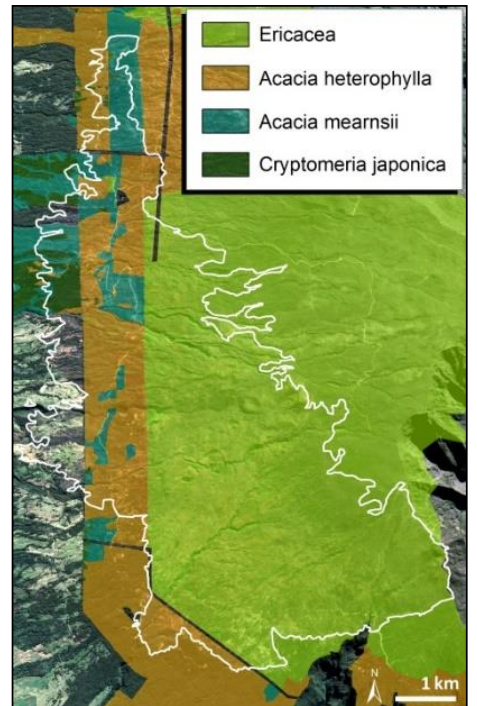

Figure 3 : Distribution of main vegetation type (@ ONF 2011).

These species are highly combustible and the area has the lowest rainfall levels on the island. These factors make this sector particularly sensitive to forest fires.

Historically, an average of 10 fires starts are recorded every year and a large one every 20 years. Figure 3 shows vegetation distribution within the 2011 burnt area. The majority of this sector is covered by Ericacea species.

\subsection{Database presentation}

This study benefits from cooperation with local actors who give SERTIT precious information concerning the different types of vegetation, burnt areas and forest regeneration (Table 1). The field campaigns made in 2012 by the National Park are not yet available.

\begin{tabular}{|c|c|}
\hline Type of data & Source \\
\hline Burnt areas in 2010 and 2011 & \multirow{3}{*}{$\begin{array}{l}\text { Reunion National } \\
\text { Park }\end{array}$} \\
\hline $\begin{array}{l}\text { « Hauts-sous-le-vent » habitat } \\
\text { typology }\end{array}$ & \\
\hline 2010 vegetation recovery & \\
\hline 2011 field survey of burnt area & \multirow{2}{*}{ ONF } \\
\hline 2011 Vegetation types & \\
\hline
\end{tabular}

Table 1 : Field data from Reunion Island National Park and ONF.

In 2005, CNES (French spatial Agency) decided to build a satellite imagery reference database over Reunion Island to help environmental studies, called "KALIDEOS-Isle Reunion". Regular acquisitions have been made since 2005 with SPOT4 and SPOT5. Pléiades data have been acquired on a theoretically monthly basis in 2012 and 2013. In addition, one Worldview-2 image was used as a pre-fire reference in 2010. A total of 44 SPOT4, 22 SPOT5, one Worldview2, 7 monoscopic and 2 stereoscopic Pléiades were used for this study (Figure 4).

All data have been ortho-rectified and corrected for atmospheric effects.

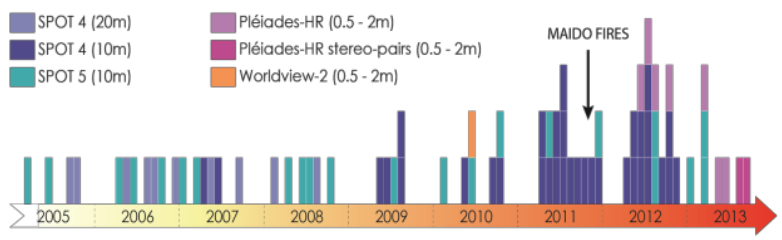

Figure 4 : Inventory of selected satellite data (@SERTIT).

\subsection{Data processing}

In this section the selected indexes used to characterize Maido pre and post fire vegetation are presented. At the beginning of this study, preliminary tests were made to choose vegetation indexes from a selection of classical vegetation indexes (DVI, RVI, NDVI) and indexes taking into account soil influences (PVI, SAVI, TSAVI and $M S A V I)$. All these indexes were computed on a high resolution (HR) and a very high resolution (VHR) image and then compared through spectral signatures analysis for different landuse class samples. Indexes showing the most important separability between landuse classes were selected for the remaining study. Finally, NDVI and TSAVI were chosen. For TSAVI, the process is constrained by the need to manually compute the soil slope axis, so we have chosen to apply it only to the VHR time series.

NDVI: Normalized Difference Vegetation Index (Rouse et Haas, 1973; Tucker, 1979)

$$
N D V I=\frac{\rho_{P I R}-\rho_{R}}{\rho_{P I R}+\rho_{R}}
$$

Where

$\rho_{P I R}:$ Near infrared reflectance

$\rho_{R}:$ Red reflectance

NDVI is computed for all HR and VHR images from the database.

TSAVI: Transformed Soil-Adjusted Vegetation Index (Baret F and Guyot G., 1991)

$$
T S A V I=\frac{a\left(\rho_{P I R}-\alpha \rho_{R}-b\right)}{\rho_{R}+a\left(\rho_{P I R}-b\right)+0.08\left(1+a^{2}\right)}
$$

Where

$a$ : Slope of the soil axis in the (R, NIR) space

$b:$ Intercept of the soil axis

TSAVI is computed for all the VHR images present in the database.

NRI: Normalized Regeneration Index (Chabaane et al., 2005)

$$
N R I=\frac{2 N D V I_{\text {post-fire }}}{\left(N D V I_{\text {post-fire }}+N D V I_{\text {pre-fire }}\right)}
$$

NRI calculation needs pre and post-fire NDVI processing. For this study, we have chosen a pre-fire reference among HR and VHR images acquired in a limited time period corresponding to the maximum of vegetation activity. 


\section{Results based on vegetation indexes}

\subsection{Results derived from NDVI SPOT data}

Index analysis was carried out at the Maido forest scale taking into account the burn scar zone, and at the plot scale using ONF vegetation types.

Results obtained with average NDVIs thanks to pre-fire SPOT time series (Figure 5) underlines the two vegetal cycle phases linked to the austral seasons. Spring growth is visible with an increase in NDVI values from November to June where maximal values are reached. Then the senescence phase sets-in characterized by a decrease of NDVI values due to reduced chlorophyll activity as vegetation dries out in the austral winter.

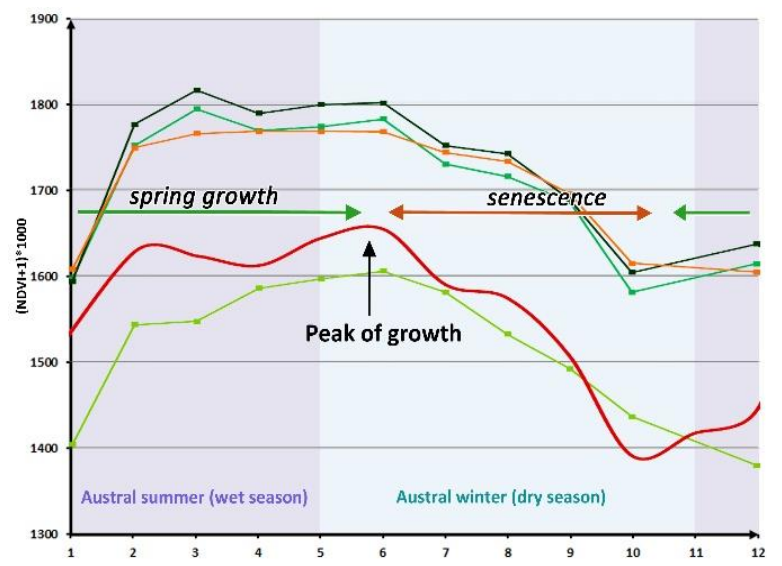

Figure 5 : Average monthly NDVI in the Maido area for the 2005-2009 period, the $x$-axis represents months ( $1=$ January, 12= December) and the y-axis indicates NDVI values (NDVI mean +1 ) ${ }^{\star} 1000$.

NDVI variation close to the 2011 Maido fire highlights the rapid photosynthetic activity decrease for each species after the November 2011 fire event (Figure 6).

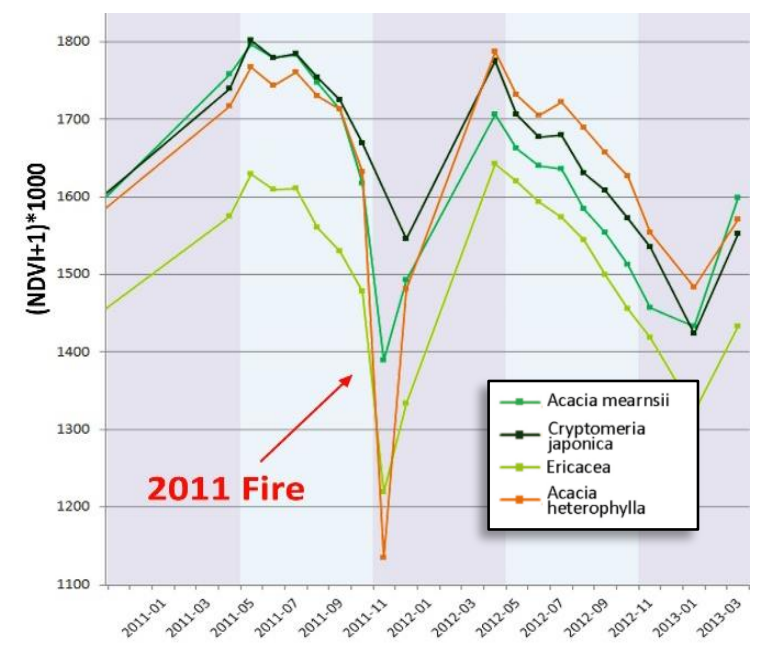

Figure 6 : NDVI variation per species highlighting the 2011 fire event.

\subsection{Results derived from TSAVI Pléiades data}

Results obtained from Pléiades data derived TSAVI variations, within the burnt area compared to a nonburnt sector (Figure 7) highlight that, up to March 2013, photosynthetic activity of both sectors varies in parallel with season effects, but with lower values for affected zone. After March 2013, the vegetation activity of the burnt areas catches up with non-burnt values until June 2013 where values are comparable.

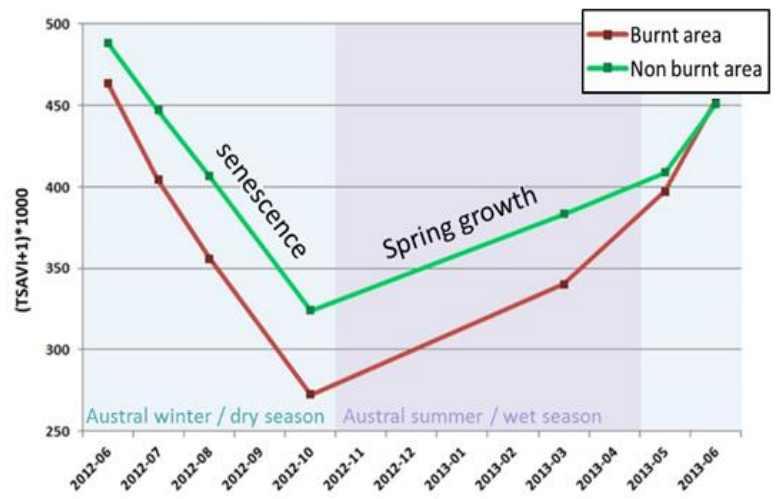

Figure 7 : TSAVI variation within burnt and non-burnt area from June 2012 to June 2013.

Vegetation recovers to its initial state by June 2013, maybe due to the probable presence of pioneer or invasive species after the fire; it would be interesting to continue monitoring into the future and to integrate field surveys to have more information concerning the vegetation species which constitute the regrowth.

\subsection{Results derived from NRI}

The NRI index is used to quantify changes of vegetation state within the burnt area taking into account the prefire state. NRI are computed from SPOT and Pléiades data. The HR and VHR pre-fire images used are respectively a SPOT5 acquired the $6^{\text {th }}$ of June 2010 and a Worldview-2 acquired the $2^{\text {nd }}$ of June 2010.

Results obtained with this index (Figure 8) show an absence of vegetation recovery just after the fire event in December 2012, and then a rapid rebound in April 2012 in the southwestern part of the burnt area. The following observations testify a change in the phenological vegetation behavior which is normally at its maximum in June. This can be explained by a rapid vegetation recovery by pioneer vegetation just after the fire which dries out quickly during the dry season. A diminution between June 2012 and June 2013 is probably due to climatic variation.

\subsection{Initial results derived from texture analysis}

Tree texture is barely visible on HR satellite images and it is difficult to differentiate low lying scrub vegetation from grassland. VHR spatial resolution offers a gain in term of precision which can be useful in understanding vegetation recovery. Figure 9 highlights at a plot scale the changes affecting the four major vegetation types. A quasi total loss of the initial texture is observed, in June 2012 (six month after the fire), and in June 2013, photosynthetic activities is visible but in the shape of a low lying vegetation this indicates a recovery by pioneer or invasive low-lying species. 

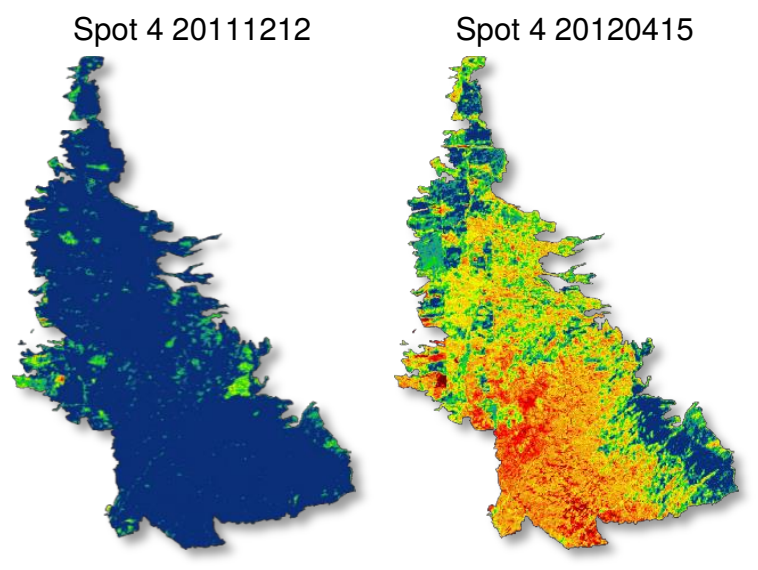

Pléiades 20120605
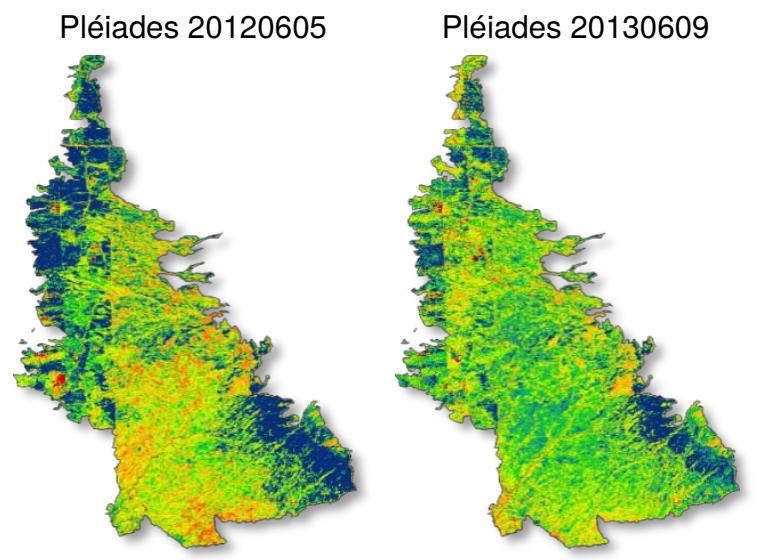

Increasing vegetation regeneration

NRI values: 0 1,2

Figure 8 : NRI variation from December 2011 to June 2013 (dates expressed as YYYYMMDD).

\section{Conclusion and perspectives}

This study concerning vegetation characterization and regeneration monitoring after the Maido November 2011 forest fires has its own unique and original character. Firstly, itis one of the first studies of austral forest fires, and secondly, it attempts to merge the use of SPOT and Pléiades image series.

At first, the SPOT KALIDEOS database was used in order to highlight normative phenological vegetation cycles of this highly endemic biotope area. Through this, establishing a seasonal behavior of vegetation makes it possible to clearly identity the fire event and its impact and, only then, is it possible to monitor postevent vegetation response with respect to an established reference. It should be noted that Pléiades data use here is of an experimental nature.

However, changes in the phenological vegetation cycle are observed with analysis of NDVI and TSAVI indexes computed from both SPOT and Pléiades data, indicating a trend which is probably due to a growth of invasive or pioneer species and therefore highlights recolonization by vegetation. The National Park of the Reunion Island has confirmed this hypothesis but field campaigns must be performed to obtain a better knowledge of local vegetation and its changes.

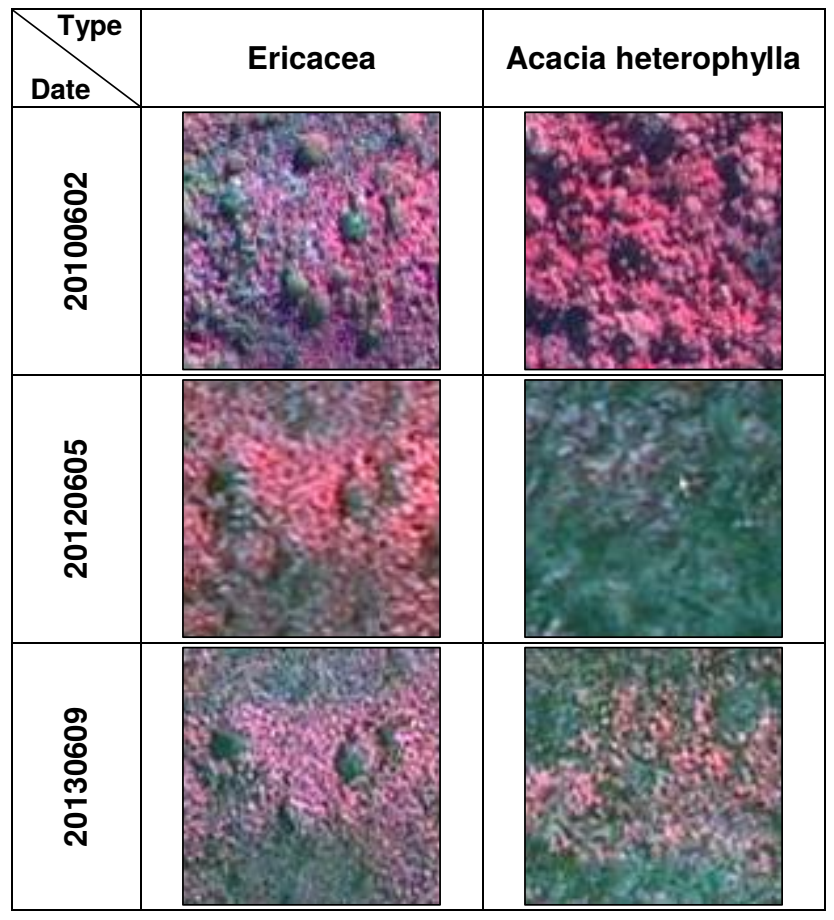

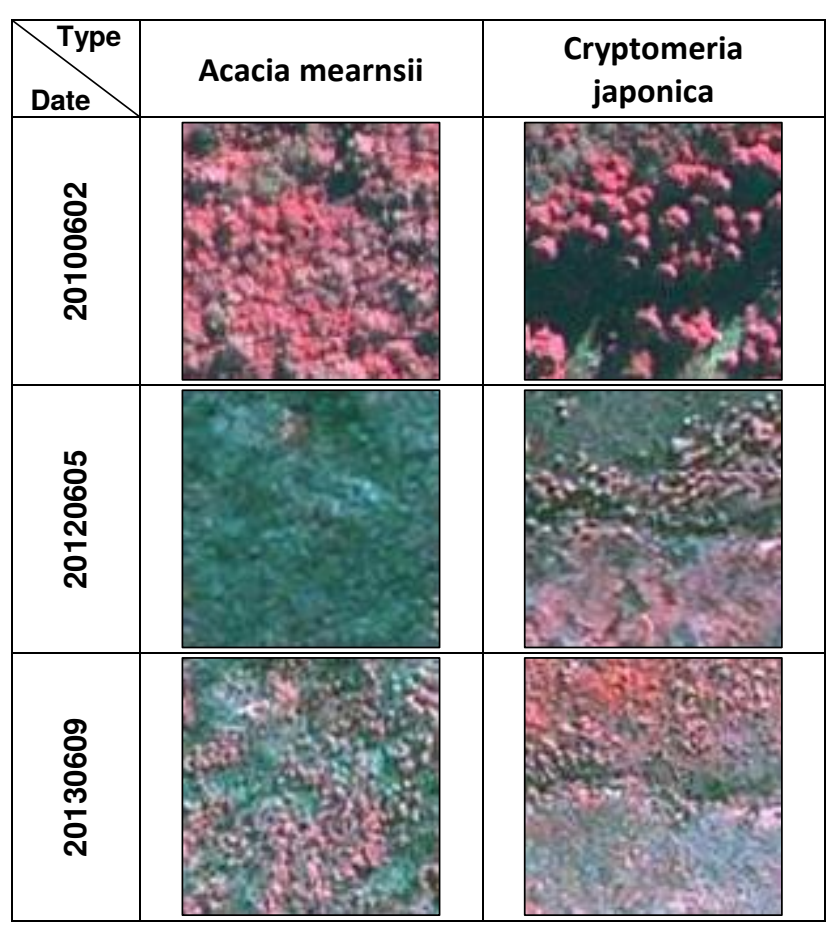

Figure 9 : Textural analysis of VHR time series in false color composition (NIR, R, G).

This study has continued in the PREFER project framework as a technical test-site with the integration of 3D information extracted from Pléiades stereo-pairs (Durand et al., 2013) to create an indicator of volume losses (Figure 10) based on simulation of vegetation heights (Figure 11) and an indicator of soil erosion vulnerability (Figure 12) based on RUSLE model family. After this phase of methodological development these indicators will be applicated to Mediterranean test-sites over Corsica and Sardinia. 


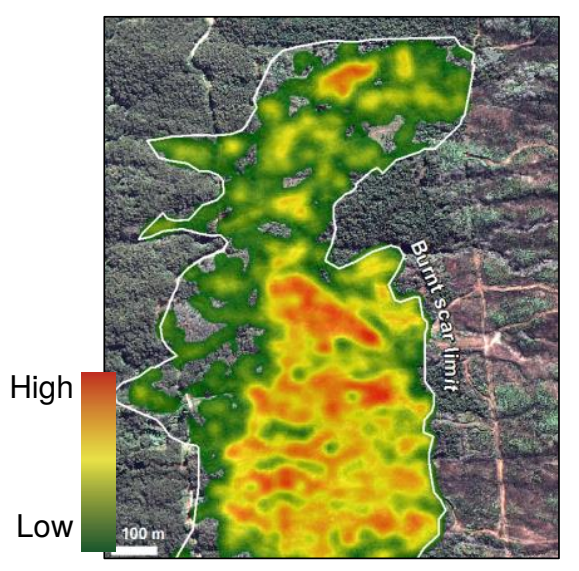

Figure 10 : Indicator of volume losses.

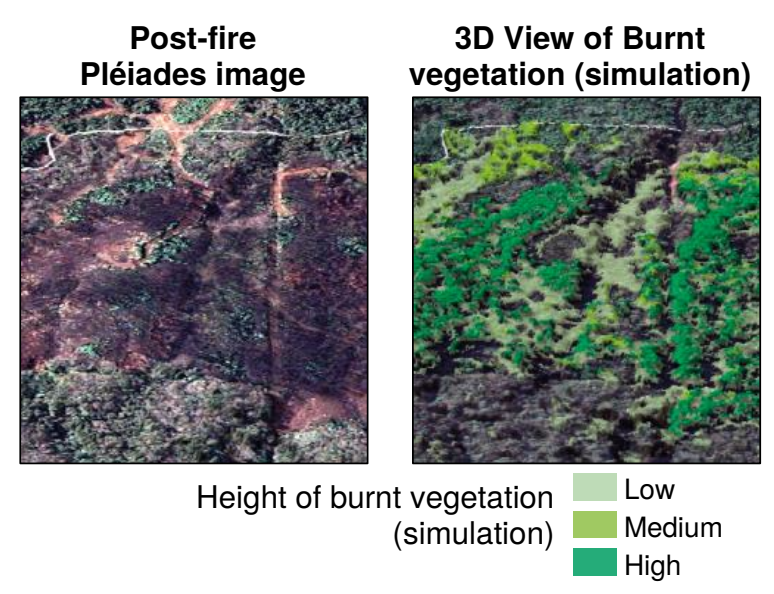

Figure 11: 3D simulation of pre-fire tree heights.
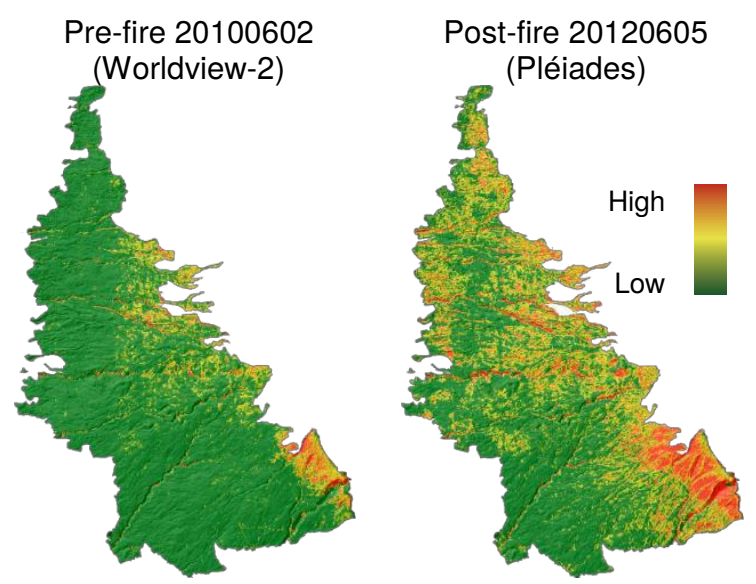

Figure 12 : Pre and post-fire soil erosion susceptibility indicator.

\section{Références}

Baret F, Guyot G, 1991. Potentials and limits of vegetation indices for $L A I$ and $P A R$ assessment. Remote Sensing of Environment, Vol. 35, 161-173.

Cadet T, 1974. Étude sur la végétation des hautes altitudes de l'île de La Réunion (Océan Indien). Vegetatio Vol.29, 2, 21-130.

Cadet T, 1980. La végétation de lîle de La Réunion. Imp. Cazal, 312 pp.

Chabaane Z. and al, 2005. Télédétection et analyse spatiale de la régénération forestière post-incendie dans le massif de boukornine au sud de Tunis. Télédétection, Vol. 5, n¹-2-3, 161-181.

Durand A., Michel J., de Franchis C., Allenbach B., Giros A., 2013. Qualitative assessment of three DSM generation approaches using Pléiades-HR data. Case study: Port-au-Prince, Haiti. Oral Presentation at 33rd EARSeL symposium, 3-6 June 2013.

Durand A., Michel J., de Franchis C., Allenbach B., Giros A., 2013. Qualité de restitution 3D par différents algorithmes appliqués à un triplet stéréo d'images satellite Pléiades sur Port-au-Prince. Présentation orale au 3ème Kal-Haiti workshop: http://kalhaiti.kalimsat.fr/IMG/pdf/04 Atelier KALHaiti 2013 MN S_Pleiades3D.pdf

Hanes, T. L., 1988. California chaparral. In: M. G. Barbour, \& J. Major (Eds.), Terrestrial vegetation of California (pp. 417-470). Davis Sacramento, CA: California Native Plant Society (Spec. Publ. No. 9).

Jakubauskas M.E., Lulla K.P., Mausel P.W. (1990). Assessment of vegetation change in a fire-altered forest landscape. Photogrammetric Engineering and Remote Sensing, Vol. 56 (3), 371-377.

Mitri G.H., Gitas I.Z., 2011. Mapping post-fire forest regeneration and vegetation recovery using a combination of very high spatial resolution and hyperspectral satellite imagery. International Journal of Applied Earth Observation and Geoinformation, Vol. 20, 60-66.

Petropoulos G.P., Griffiths H.M., Kalivas D.P., 2014. Quantifying spatial and temporal vegetation recovery dynamics following a wildfire event in a Mediterranean landscape using EO data and GIS. Applied Geography, Vol. 50, 120-131.

Préfecture de la Réunion - Direction de l'agriculture et de la forêt, 2009. Plan départemental de protection des forêts contre l'incendie 2009/2015 La Réunion.

Riano D., Chuvieco E., Ustin S., Zomer R., Dennison P., Roberts D., Salas J., 2002. Assessment of vegetation regeneration after fire through multitemporal analysis of AVIRIS images in the Santa Monica Mountains. Remote Sensing of Environment, Vol. 79, 60- 71.

Röder A., Hill J., Duguy B., Alloza J.A., Vallejo R., 2007. Using long time series of Landsat data to monitor fire events and post-fire dynamics and identify driving factors. A case study in the Ayora region (eastern Spain). Remote Sensing of Environment, Vol. 112, 259273. 
Rouse J.W., Haas R.H., Schell J.A., Deering D.W., 1973. Monitoring vegetation systems in the Great Plains with ERTS. In 3rd ERTS symposium, NASA SP-351 I (pp. 309-317).

Tucker CJ, 1979. Red and photographic infrared linear combinations for monitoring vegetation. Remote Sensing of the Environment, Vol. 8, 127-150.
Veraverbeke S., Verstraeten W.W., Lhermitte S., Goossens R., 2010. Evaluating Landsat Thematic Mapper spectral indices for estimating burn severity of the 2007 Peloponnese wildfires in Greece. International Journal of Wildland Fire, Vol. 19, 558-569. 